\title{
Changes in the source and transport mechanism of terrigenous input to the Indian sector of Southern Ocean during the late Quaternary and its palaeoceanographic implications
}

\author{
M Thamban ${ }^{1 *}$, S S NAik ${ }^{1}$, R Mohan $^{1}$, A RajakumaR ${ }^{1}$, N Basavaiah ${ }^{2}$, Witty D'Souza ${ }^{1}$, \\ Sarita Kerkar ${ }^{1}$, M M Subramaniam ${ }^{1}$, M SudhaKAR ${ }^{1}$ and P C PANDEY ${ }^{1}$ \\ ${ }^{1}$ National Centre for Antarctic and Ocean Research, Headland Sada, Goa 403 804, India. \\ ${ }^{2}$ Indian Institute of Geomagnetism, Kalamboli, New Panvel (W), Navi Mumbai 410 218, India. \\ *e-mail: meloth@ncaor.org
}

\begin{abstract}
Changes in the terrigenous sediment source and transport mechanisms during the late Quaternary have been investigated using four sediment cores within the Indian sector of Southern Ocean, using the magnetic susceptibility (MS) and sedimentological records. Sediments deposited during the Holocene and other interglacial periods were characterised by low MS, low sand content, reduced ice-rafted detritus (IRD) input and increased illite possibly transported via hydrographic advection from the south. The glacial intervals are characterised by high MS, high sand content, increased IRD input and reduced illite clays, derived from both local as well as Antarctic sources. Significant reduction in clay fraction and illite content during glacials suggests that the erosive and transporting capabilities of the deep and bottom waters could have reduced compared to the interglacial times. The changes in terrigenous influx to this region were significantly influenced by the rhythmic glacial-interglacial fluctuations in bottom circulation and the position of the Polar Front.
\end{abstract}

\section{Introduction}

Southern Ocean plays a significant role in the global climate cycle due to its vital influence on processes such as the formation and spreading of major watermasses, currents, deep-ocean ventilation, nutrient cycling, atmospheric heat transfer as well as sea-ice formation (Knox and McElroy 1985; Toggweiler and Sarmeinto 1985; Martin 1990). Understanding the past changes in circulation, sedimentation, biological productivity of the Southern Ocean and its possible influence on the global oceanic processes are therefore, important in deciphering the global climate change. Although several studies (mainly in the Atlantic and Pacific sectors) have been initiated in this regard, the palaeoceanography of the Indian sector $(\sim 40 \%)$ of the Southern Ocean remains largely unexplored. Faunal studies on the sediment records from the Indian sector of the Southern Ocean indicated that the Antarctic Polar Front shifted towards the equator by more than $5^{\circ}$ of latitude (CLIMAP 1976; Crosta et al 1998). The palaeoceanographic history of the region is not only controlled by the dynamic positioning of the oceanic fronts, but also on the changes in important watermasses such as Antarctic Bottom Water and strong currents related to the Antarctic Circumpolar Current (Klinck and Smith 1993; Bareille et al 1994; Labeyrie et al 1996; Dezileau et al 2000; Crosta and Shemesh 2002; Mackensen 2004).

Terrigenous sediments in the Atlantic and Indian sectors of the Southern Ocean are dominated by silt and clay-sized material with small proportions

Keywords. Magnetic susceptibility; terrigenous flux; late Quaternary; Southern Ocean. 
of sand and gravel delivered by icebergs and/or sea-ice (Diekmann et al 2004). The spatial and temporal changes in the detrital influx during the last climatic cycle in this region suggest a general increase in detrital material during the coldest periods (Bareille et al 1994). However, the origin and transport mechanisms of detrital materials in the Southern Ocean has been a matter of intense debate. Petit et al (1990) suggested that increased dust particles, mostly originated from Patagonian loess accumulated in the Antarctic ice during glacial periods. Similar enhanced terrigenous material in the Southern Ocean during the glacial periods have been ascribed to possibly airborne dust, also leading to an increase in iron input to the glacial Southern Ocean that initiated a stronger biological pump, thus affecting the carbon cycle (Martin 1990). However, detailed provenance studies of the fine fraction of marine sediments within the Indian sector of the Southern Ocean based on mineralogical, geochemical and isotopic methods rule out any significant aeolian supply (Bareille et al 1994; Dezileau et al 2000).

Although the ice-rafted detritus (IRD) contributes less than $20 \%$ of the total detrital input to the SE Indian Ocean, it provides important information on changes in surface hydrography and ice sheet dynamics in relation to climate changes (Bareille et al 1994). Based on isotopic studies, they suggested that most of the IRDs present in this area have been originated from the eastern Antarctic along with a variable input from western Antarctic. Sediment core studies from the Southern Ocean also suggested that large-scale changes occurred in the supply of IRDs throughout the late Quaternary (Labeyrie et al 1986). Due to the close relationship between detrital flux variations and magnetic susceptibility (MS) variations, the MS records of sediment cores have been proven to be a reliable and important proxy for identifying the modern distribution as well as past changes in detrital input to the Southern Ocean (Bareille et al 1994; Dezileau et al 2000; Pirrung et al 2002; Diekmann et al 2004; Schmieder 2004). In several Southern Ocean records, the down core magnetic susceptibility data have also been used as a chronological tool and to improve the existing age models (von Dobeneck and Schmieder 1999; Crosta and Shemesh 2002; Schmieder 2004). Further, the concept of orbital tuning of magnetic susceptibility records has proved to be of immense value in establishing high-resolution age models in the Milankovitch and Sub-Milankovitch bands, especially for the Southern Ocean records (von Dobeneck and Schmieder 1999; Schmieder 2004). In this study, we have investigated the variations in magnetic susceptibility, grain-size, clay mineralogy and IRDs within the four sediment cores collected from the Indian sector of the Southern Ocean. The main objective of this study was to decipher the source and the transport mechanisms of terrigenous influx and its palaeoceanographic history during the late Quaternary.

\subsection{Oceanographic setup}

Modern circulation in the study area is mainly influenced by wind stress, deep convection and cyclonic gyres. Frontal regions, where watermasses meet and exchange heat and salt, are dynamic features and influence the biogeochemical cycle of the study region. Major currents such as the wind-driven Antarctic Circumpolar Current (ACC) transfer more than 100 Sverdrup of water in the eastward direction as a narrow band between $46^{\circ} \mathrm{S}$ and $43^{\circ} \mathrm{S}$ (Park et al 1993) and therefore could influence the dispersal and redistribution of the sediment. The Antarctic Bottom Water (AABW) originates near the Antarctic continent and spreads northward along the seafloor below $4100 \mathrm{~m}$ water depth (figure 1), effecting the sediment transport from south to north (Kolla et al 1976). Important watermasses like the Circumpolar Deep Water (CDW; 2000-3800 m) and Antarctic Intermediate Water (AAIW; 1100-1300 m) have significant bearing on the oceanography of the study region (Park et al 1993; N. Anilkumar, unpublished data).

\section{Material and methods}

As part of the Pilot Expedition to the Southern Ocean (PESO), as many as eight piston/gravity sediment cores were collected along a meridional transect from the Indian sector of the Southern Ocean onboard ORV Sagar Kanya during its 200th expedition from January to March 2004 (figure 1). The sediment cores were sectioned onboard. Lithological and colour variations were noted. Sediments were sub-sampled at every $1 \mathrm{~cm}$ for the first $100 \mathrm{~cm}$ and at every $2 \mathrm{~cm}$ for the remaining length. Samples were stored in clean, labelled polythene sample bags. Proper care was taken to avoid external contamination and cross-sample contamination. The present study deals with four sediment cores (SK-200/14, 22a, 27 and 33) collected at water depths between 2300 and $4400 \mathrm{~m}$. The length of the sediments recovered varies from $480 \mathrm{~cm}$ to $1020 \mathrm{~cm}$. These cores represent unique oceanic regimes within the Southern Ocean (table 1 and figure 1). Of the four, two cores (SK-200/22a and SK-200/27) were selected for detailed sedimentological, mineralogical and microscopic studies to understand the origin and transport mechanisms of detrital fluxes. 


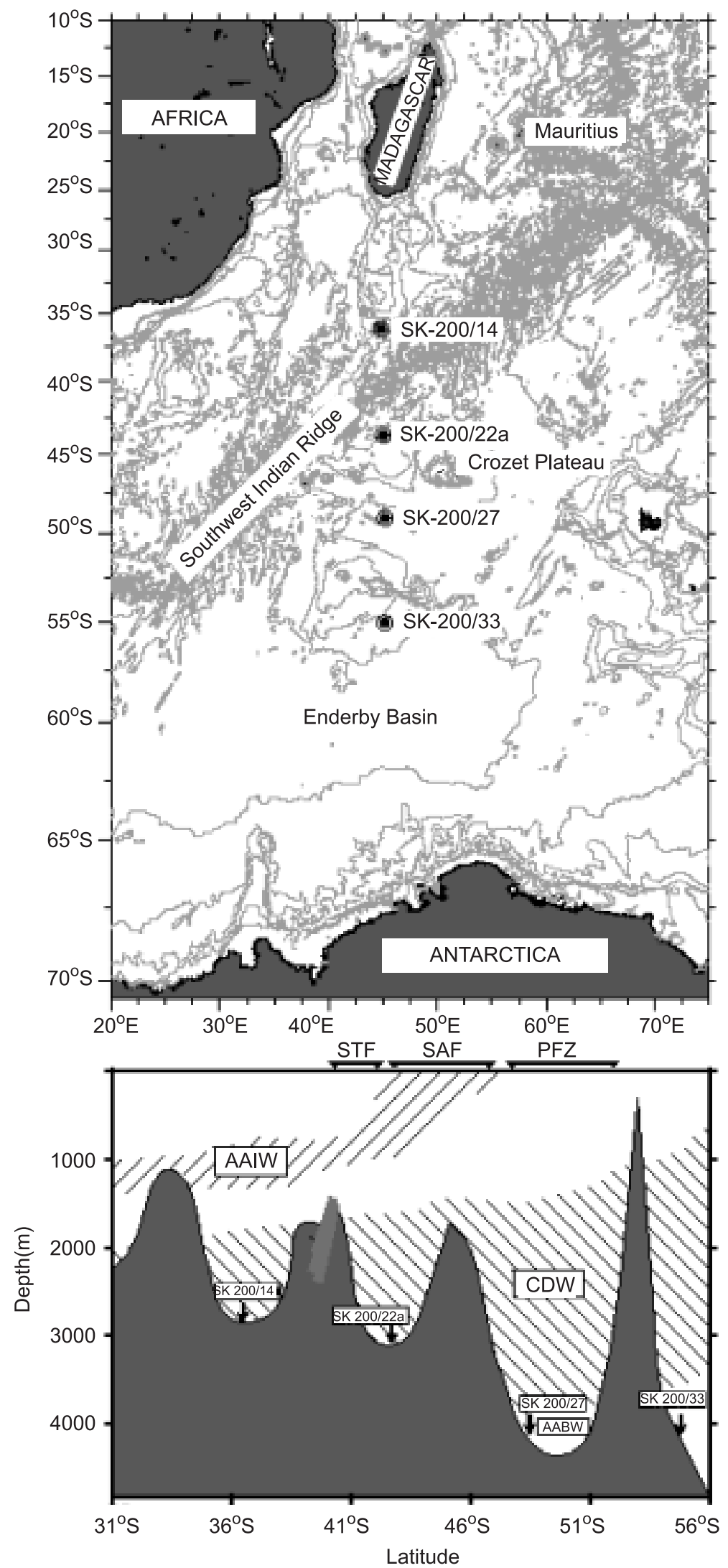

Figure 1. Study area showing: bathymetry and piston and/or gravity core locations (top) and a schematic diagram showing a vertical transect along $45^{\circ} \mathrm{E}$ with position of cores relative to that of major watermasses (bottom). AABW - Antarctic Bottom Water; CDW - Circumpolar Deep Water; AAIW - Antarctic Intermediate Water; STF - Subtropical Front; SAF - Subantarctic Front; PFZ - Polar Front Zone (based on: Park et al 1993; Anilkumar et al 2005; Anilkumar, unpublished data). 
Table 1. Location and core details.

\begin{tabular}{clccccc}
\hline & & & \multicolumn{2}{c}{ Location } & & Core length \\
\cline { 3 - 4 } Sl. no. & Core no. & Depth $(\mathrm{m})$ & Lat. ${ }^{\circ} \mathrm{S}$ & Long. ${ }^{\circ} \mathrm{E}$ & & \\
\hline 1. & SK-200/14 & & Oceanic regime \\
\hline 2. & SK-200/22a & 2730 & $36^{\circ} 07^{\prime}$ & $44^{\circ} 50^{\prime}$ & 592 & Subtropical region \\
3. & SK-200/27 & 4377 & $43^{\circ} 42^{\prime}$ & $45^{\circ} 04^{\prime}$ & 754 & Subantarctic region \\
4. & SK-200/33 & 4204 & $59^{\circ} 00^{\prime}$ & $45^{\circ} 13^{\prime}$ & 489 & Antarctic Polar Front \\
\hline
\end{tabular}

For magnetic susceptibility (MS) measurements, wet sediment samples were packed in $10 \mathrm{cc}$ plastic sample vials and analysed at the Indian Institute of Geomagnetism (IIG), Navi Mumbai. Measurements of volume-specific magnetic susceptibility $\left(\kappa ; 10^{-5}\right.$ SI units) were carried out using a Bartington MS-2 magnetic susceptibility meter and an MS2B dual frequency sensor. Duplicate measurements were performed at low $(0.47 \mathrm{kHz})$ and high $(4.7 \mathrm{kHz})$ frequencies on all samples. The differences in MS values between low and high frequencies are found to be extremely negligible and therefore the frequency-dependent susceptibility in present core samples was not considered. Sediments of the cores were subjected to size fraction analyses following pipette analyses. The $<2 \mu \mathrm{m}$ fraction of the selected sediment samples from both the cores were studied for clay mineralogy, using Philips X-ray diffractometer (1840 Model) (see Thamban et al 2002 for details of sample preparation, analysis and quantification). The coarse fractions of the representative sediment samples were observed under binocular microscope to identify the Ice Rafted Detritus (IRD).

Stratigraphy of the sediment cores is based on the magnetic susceptibility (MS) data that clearly reveal the glacial-interglacial cycles (figure 2). Increased magnetic susceptibility values within the Southern Ocean were found to truthfully record the increased terrigenous flux, mainly related to ice rafting during cold glacial periods (Bareille et al 1994; Crosta and Shemesh 2002). Indeed, 'magnetic cyclostratigraphy' - a relatively new method - has successfully been established as a very efficient chronology tool for marine sedimentary sequence, especially in the Southern Ocean (von Dobeneck and Schmieder 1999; Crosta and Shemesh 2002; Schmieder 2004). Using the magnetic susceptibility records and by comparison with the detailed records of Bareille et al (1994), Dezileau et al (2000) as well as Crosta and Shemesh (2002) within the Indian sector of the Southern Ocean, stratigraphic tie points and major glacialinterglacial stages were identified (figure 2). While doing so, variations in the grain size and IRD content were also taken into consideration. The core SK-200/33 is the longest one $(1012 \mathrm{~cm}$; table 1$)$ and exhibits several cycles within the MS data.
For convenience, only the top $3 \mathrm{~m}$ data is given here, in which the recent cycle is comparable to that of the above cores (figure 2). This entire core may represent the sedimentary record of the last 1 million years or so, as revealed by the excellent match of MS record to the stacked South Atlantic MS records (SUSAS stack) that had been orbitally tuned and widely used as a stratigraphy tool analogous to the SPECMAP in the Southern Ocean (von Dobeneck and Schmeider 1999; Schmieder 2004). For SK-200/14, although stratigraphic control points have been obtained based on MS data, it is prone to error due to the presence of ferromanganese nodules at subsurface depths (between 76 and $120 \mathrm{~cm}$ of the core) and possible differences in the source of detrital fluxes (mostly from Africa and Madagascar region), compared to other cores. We believe that the interval of $\mathrm{Fe}-\mathrm{Mn}$ nodule abundance at the SK-200/14 site marks a dramatic change in the rate of sedimentation and the supply of elements like $\mathrm{Fe}-\mathrm{Mn}$ which, most probably corresponds to the period last glacial maximum $(\mathrm{LGM} \sim 17-25,000$ years before present).

\section{Results and discussion}

The sediment cores studied here represent distinct oceanic environments and reveal characteristic temporal variations in lithology and magnetic susceptibility. Core SK-200/14 exhibits three lithological units: the top unit (unit 1) consists of pale yellowish (10YR 8/6) carbonate-rich, silty sand with MS values as low as 2.0 SI units (figure 2); the unit 2 is characterised by greyish orange (10YR $7 / 4$ ) sandy sediments with abundant manganese nodules (up to $\sim 5 \mathrm{~cm}$ in diameter) as a layer between 76 and $120 \mathrm{~cm}$ below the surface and varied MS values between 9 and 39 SI units. Unit 3 sediments are greyish yellow (5Y 8/4) clayey sediments with large oscillations in MS values (between 7 and $44 \mathrm{SI}$ ).

Core SK-200/22a exhibits large changes in lithology, colour and MS. The top unit (unit 1) consists of calcareous white (N9) to light grey (N7) sandy silt/clay with relatively low MS values (av. $13 \mathrm{SI}$ ) till $115 \mathrm{~cm}$ below the surface (figure 2). A silty-clay 

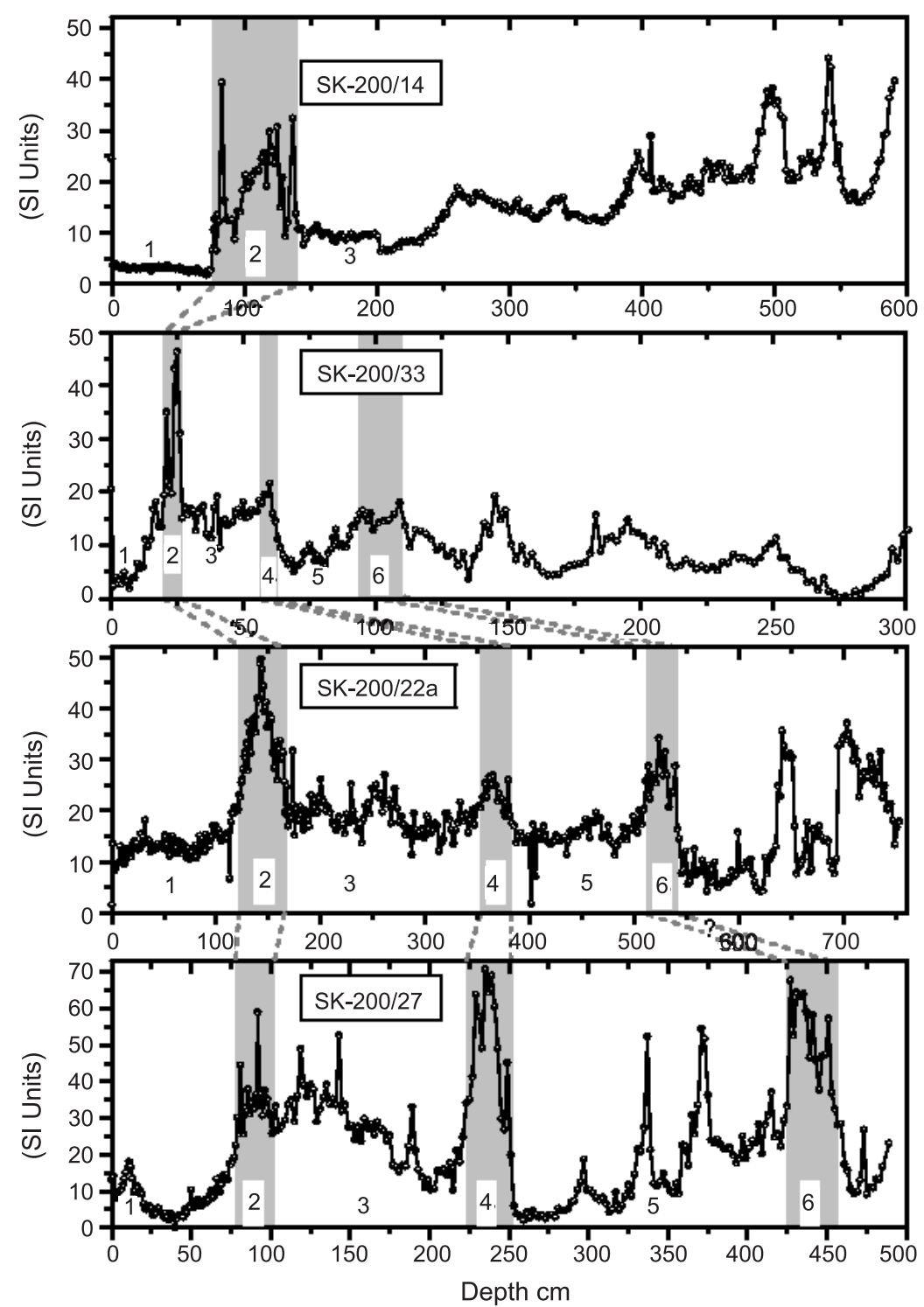

Figure 2. Magnetic susceptibility records of various cores discussed in the study. Stratigraphy is based on correlation with the MS records of well-dated cores from this area as well as with the stacked SUSAS record (von Dobeneck and Schmieder 1999). Shaded areas represent glacial periods and the numbers represent the SPECMAP stages (see text).

dominated dark greyish band with exceptionally high MS values (up to $50 \mathrm{SI}$ ) is found between 130 and $148 \mathrm{~cm}$ depth (unit 2). Below this layer, the unit 3 sediments are dominated by light grey clays with rhythmic changes in MS values between 5 and $35 \mathrm{SI}$ units. The sand content varies between 6 and $28 \%$ and increased sand content exhibits excellent match with increased MS values. Illite and smectite are the dominant minerals throughout the cores. Illite $(65 \%)$, followed by smectite $(24 \%)$ are present in Holocene and other interglacial sections, while in the glacial intervals illite ranges up to $51 \%$ and smectite increases to $32 \%$.

The core SK-200/27, situated on the rim of a sensitive oceanic region (Polar Front Zone) shows distinct variations in lithology and susceptibility values. This core consists of alternating layers of greyish orange (10YR 7/4), siliceous (diatom-rich) clayey sediments with low MS values (least value -2 SI) and light olive grey (5Y 5/2) sandy sediments interspersed with gravel-sized IRDs showing very high MS values (up to $68 \mathrm{SI}$ ). Sand content of the sediment (2 to $31 \%$ ) co-varied with large scale changes in MS. Illite (58\%) followed by smectite $(27 \%)$ are dominant in Holocene and interglacial sediments, whereas smectite content increased (46-67\%) and illite content decreased $(27-36 \%)$ in the sediments of the glacial periods (figure 3).

Core SK-200/33 that was collected from the modern Polar Frontal Zone $\left(55^{\circ} \mathrm{S}\right)$ also reveals rhythmic variations in colour, lithology, IRDs as 


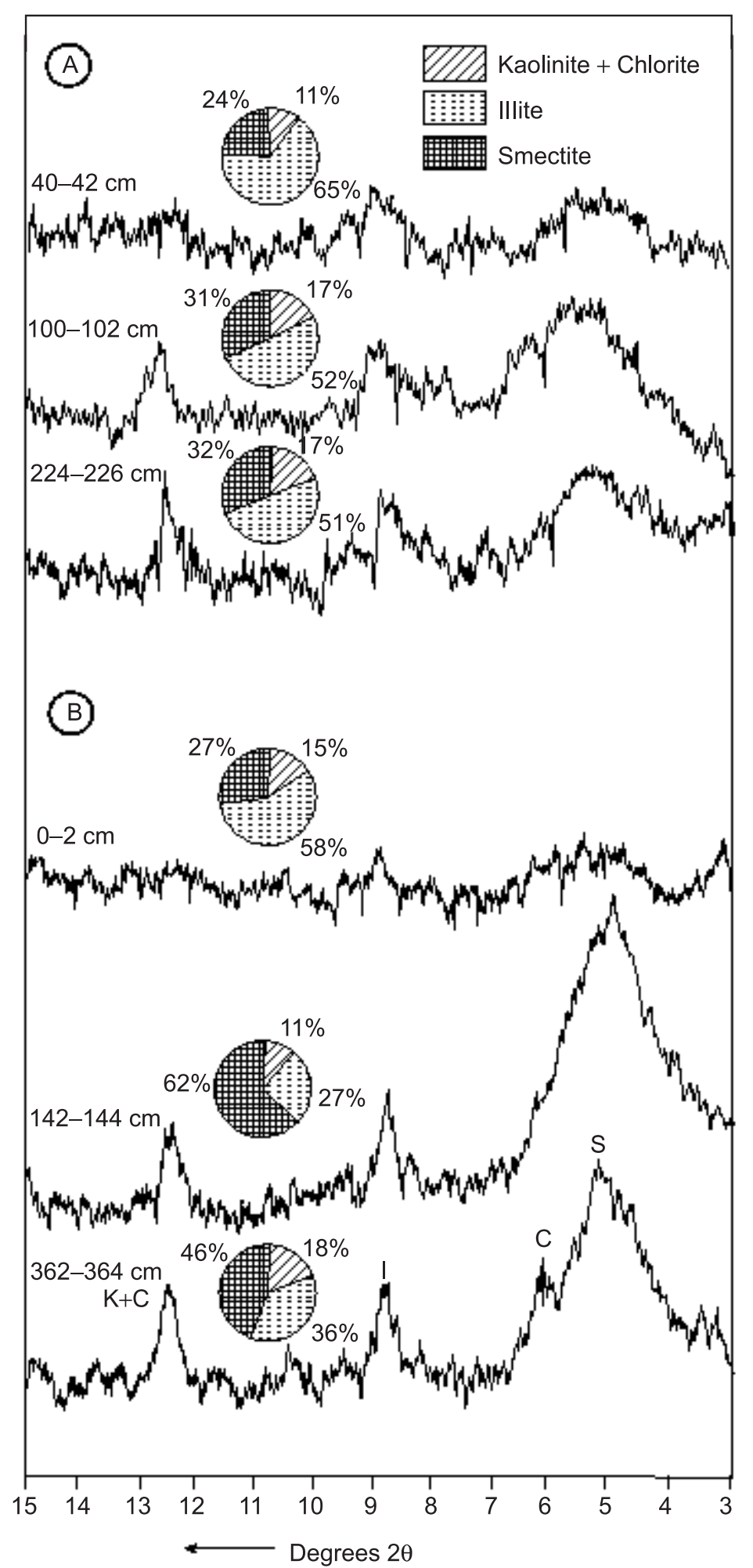

Figure 3. Representative X-ray diffractograms showing major clay minerals in SK-200/27 (A) and SK-200/22a (B). Pie diagrams show the relative weight percentages of the different clay minerals.

well as MS values. Alternating layers of light olive grey (5Y 6/1) diatom-rich sediments with low MS values (as low as $2 \mathrm{SI}$ ) and yellowish grey (5Y 8/1), clayey sediments with high MS values (up to $46 \mathrm{SI}$ ) are found throughout the core.

\subsection{Sediment source and transport} mechanisms

The magnetic susceptibility of marine sediments reflect the varying terrigenous input related to the 


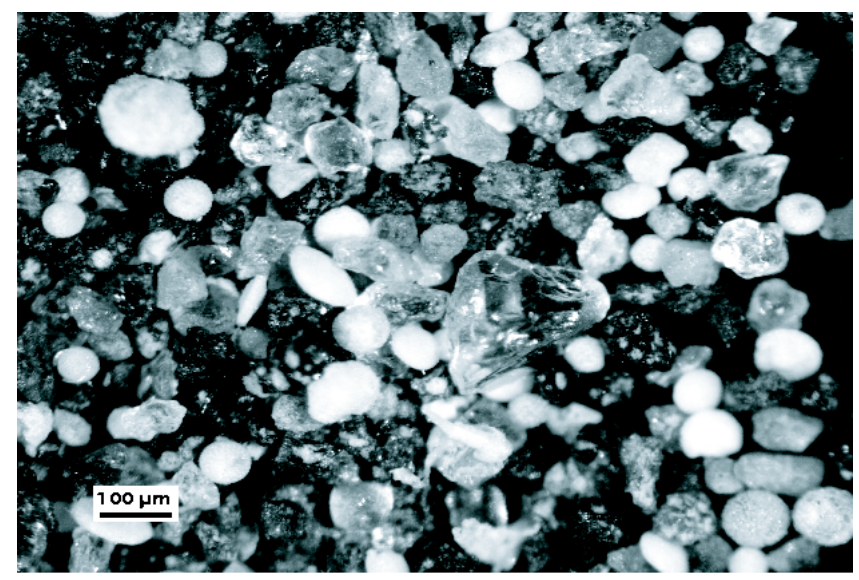

Figure 4. Photomicrograph showing dominance of IRDs (fresh quartz grains and dark volcanic material) compared to the biogenic microfossils (white) within the sediments deposited during LGM in core SK-200/27.

continental and submarine erosion and/or volcanic and cosmic dusts, carbonate production/ dissolution as well as transport mechanisms and diagenesis (see Fredrichs et al 1999 for an overview; Ellwood et al 2000). In order to substantiate our findings that the changes in magnetic susceptibility actually record the fluctuations in detrital input, the sand $(>63 \mu \mathrm{m})$ content and the occurrence of ice rafted detritus (IRD) within the coarse fraction for cores SK-200/27, SK-200/22a as well as SK200/33 were also examined. The IRDs consisting of unsorted quartz grains and dark rock fragments (mostly bigger than few millimetres) are disseminated throughout the core SK-200/27 (figure 4). $\mathrm{X}$-ray diffraction studies of the dark grains within the coarse fraction of core SK-200/27 revealed dominance of typical mafic volcanic minerals like plagioclase feldspars (low albite) and pyroxenes (aegyrine augite and enstatite), suggesting its derivation from volcanic sources. The down-core variation of MS correlated well with sand percentage and IRD occurrence. The Holocene section within the core SK-200/27 is characterised by very low sand content $(<10 \%)$, MS $(<15$ SI) values, and extremely low IRD content. The IRD content in this core increased $>100$ times during the LGM, compared to the Holocene. Similar dramatic glacial-interglacial decrease in IRD content is also evident in SK-200/33 and SK-200/22a. It is noted that the IRD content in the northern core (SK-200/22a) is much less than the southern one. Our studies therefore, confirm that MS records of the sediment cores in the study area faithfully depict the fluctuations in detrital sediment influx.

The presence of both volcanic rock fragments and unsorted, fresh quartz grains within the IRDs during the glacial intervals in SK-200/27 suggests two detrital sources to the study region: quartz mostly derived from the Precambrian crystalline rocks of Antarctic craton and the volcanic material possibly derived from Crozet and Prince Edward Islands. Therefore, our data support a dual origin for the detrital material as well as an increase in detrital input to the SW Indian sector of the Southern Ocean during glacial periods which may be due to the northward migration of Polar Front Zone. On the basis of IRD analyses, Bareille et al (1994) suggested possible detrital supply both from local and Antarctic sources in the sediment cores from the SE Indian Ocean. Increased ice-rafting during glacial stages is also supported by the oxygen isotope anomalies reported in a sediment core from $44^{\circ} \mathrm{S}$ in the SW Indian Ocean, which was interpreted as due to an enormous supply of melt water to the surface waters of Antarctic Polar Front (Labeyrie et al 1986). However, the relative significance of Antarctic and local sources for the detrital flux in the study area are not exactly known and would depend on the proximity to the core locations and transport mechanisms involved.

Although the detrital supply by ice rafting appears to be significant, the sand fraction consisting of IRDs contribute less than $30 \%$ of the total detrital input even during the glacials. Both the cores SK-200/27 $\left(49^{\circ} \mathrm{S}\right)$ and SK-200/22a $\left(43^{\circ} \mathrm{S}\right)$ are dominated by silt and clay and it is obvious that even during the glacial times, ice rafting was responsible for relatively a small percentage of the total detrital supply to the study area. The dominance of illite clays in both SK-200/22a and SK-200/27 further support significant supply of detrital material by currents and/or watermasses. Within the Southern Ocean, illite is the characteristic clay mineral derived from physical weathering of the Antarctic crust and its presence is used to demonstrate the Antarctic contribution (Bareille et al 1994). We therefore, propose hydrographic advection as an important transport mechanism throughout the late Quaternary that could have controlled and contributed to the detrital influx to the study area. As this region is characterised by major watermasses (AABW and CDW) and strong currents (ACC), they contribute significantly to the present day bottom sediment transport and formation of nepheloid layer (see Kolla et al 1978; McCave 1986). Any changes in the strength and direction of any of these watermasses/currents can lead to significant changes in the bottom water activity and sediment transfer ability. Based on the relative decrease in clay fraction and increase in sand content (mainly IRDs) as well as decrease in illite content during the glacial periods, we infer that the erosive and transporting capabilities of the deep and bottom waters at the core sites could have slightly reduced compared to the modern 
conditions. Ehrmann and Grobe (1991) also found that the cyclic sedimentation at the SE Indian basin corresponds to the glacial to interglacial cycles and further inferred that the AABW was less erosive during the glacials than the interglacial times. Since the formation of AABW itself is influenced by factors such as the supply of the dense Ice Shelf Water (ISW), North Atlantic Deep Water (NADW) as well as the permanent sea-ice cover over Antarctic waters, changes in the status of any or all of these could have slowed down its formation and spreading of bottom and deep waters (Bareille et al 1994). However, our data do not support any cessation or major weakening of the formation and spreading of AABW due to the large amount of fine-sized material and illite clays present even during the glacial times.

Besides the advection by bottom currents, the exposed shelf region during glaciation, would have allowed additional input of terrigenous material to the deep sea through bottom currents and slumping. Increase in smectite content, especially during the glacial stages at SK-200/22a suggests an increased chemical weathering and removal of smectite-rich clays from the volcanic rocks (Crozet and Prince Edward Islands) as well as the SW Indian Ridge. A systematic decrease in illite content is also evident from south to north (SK-200/27 - illite 51-65\%; SK-200/22a - 27-58\%), suggesting the influence of bottom waters from south in the supply of fine material. Such variations could also be related to the fact that the SK-200/22a core site is from $\sim 2700 \mathrm{~m}$ water depth, above the influence of AABW as well as due to the presence of topographic barriers like Crozet Plateau. Additionally, the stronger surface wind-forcing during the glacial periods could have also increased the transporting capacity of the ACC (Pudsey and Howe 1998).

The magnetic susceptibility records in the present study area correlate well with the dust flux records of the Vostok ice core (Petit et al 1990), showing highly increased dust values during the glacial periods compared to the modern and other interglacial periods. Such a comparison may even advocate for a common origin as anticipated by the 'iron hypothesis' (Martin 1990). However, the available data negate any significant aeolian input to the Indian sector of the Southern Ocean (Bareille et al 1994; Dezileau et al 2000). Most of the dust flux during the LGM was attributed to be of Patagonian (Argentina) origin (with typical Precambrian cratonic signatures), and may constitute only $<5 \%$ of the total estimated terrigenous flux to the Indian sector of the Southern Ocean (Dezileau et al 2000; Diekmann et al 2004). Instead the similarity between dust signals in ice core and detrital signals in oceanic records may support a common forcing mechanism - global glaciation and its potential feedback mechanisms. We therefore, suggest that the global ice volume changes and the resultant sea level fluctuations could have effectively changed the terrigenous material transport to the core sites via shelf erosion (ice rafting and bottom currents) as well as hydrographic advection from south. Origin of terrigenous fluxes at the northern-most site (SK-200/14) appears to be different from other sites in this study, as is suggested by lithology and MS data. Since the core site is from north of the SW Indian Ridge (which acts as a physiographic barrier), any supply from south would be highly reduced and detrital material would be originated mainly from the AfricanMadagascar region.

\subsection{Cyclic sedimentation and palaeoceanographic implications}

The rhythmic oscillations revealed by the MS and other sedimentological parameters are comparable to the glacial-interglacial changes observed in the Atlantic and Indian sectors of the Southern Ocean (see Bareille et al 1994; Pudsey and Howe 1998; Crosta and Shemesh 2002; Schmeider 2004). The Holocene and other interglacials in cores SK200/22a, SK-200/27 and SK-200/33 are characterised by low MS, low sand content, low IRD input and an increased input of illite clays. The glacial intervals reveal that IRD input increased both from local and Antarctic sources, whereas the advection of fine clays from Antarctic region reduced significantly. During the glacial periods, due to the lowering of sea level and the resultant increase in exposure of the shelf area of the islands, larger areas would have been eroded and supplied the detrital material via turbidity currents to the core sites as well as due to the increased sea-ice rafting. Although the location of SK-200/27 core is out of the modern winter sea ice limit, it is possible that any change in the position of the same during glacial periods may greatly alter the same. This supports the earlier suggestion based on the marine diatom studies that during the last glacial maximum (LGM), the winter sea ice edge within the southwestern Indian Ocean shifted much northward beyond the present position (Crosta et al 1998).

We propose that the past changes in terrigenous influx to this region were significantly influenced by the glacial-interglacial changes in the oceanic circulation and the position of the polar front (PFZ). As discussed in the earlier section, it is obvious that the strength of the glacial bottom waters in the study area were diminished compared to the modern conditions. The latitudinal variations among the core records also have significant 
palaeoceanographic implications as it is a clear indication of the influence of watermasses and/or currents on lithogenic sedimentation, in response to the glacial-interglacial oceanic changes. A model study suggested that increase in the wind-stress would result in increased transport by ACC during glacial times (Klinck and Smith 1993). Such enhancement in bottom currents is suggested to increase the terrigenous transfer by re-suspension processes (Dezileau et al 2000). However, since the wind-driven ACC is east-flowing, this would mean that the effect of enhanced ACC will transport the sediments from west to east rather than from south to north. We do not have sufficient data at this juncture to evaluate the influence of such major changes in ACC on the sediment transport to the study area. However, evidence do suggest the existence of detrital influx of Antarctic origin in the core sites related to the advection via AABW to the Indian sector of Southern Ocean. The environmental information obtained from the northern core (SK-200/14) is different from other records as the position of this core location (north of the SW Indian Ridge) makes it less influenced by southern waters. Presence of manganese nodules and micro-nodules and enhanced MS values at subsurface depths $(76-120 \mathrm{~cm}$ below sea floor) within the core suggest a dramatic change in sea floor environment as well as decreased sedimentation rates, allowing authigenic nodule formation.

\section{Conclusions}

Magnetic susceptibility records of the four sediment cores faithfully depict the fluctuations in detrital sediment input, as substantiated by the correlation with the sand fraction and the occurrence of IRDs. The rhythmic oscillations in MS and other sedimentological records are closely comparable to the glacial-interglacial changes reported in the Southern Ocean and indicate variations in the sources and modes of sediment supply. The presence of volcanic material and quartz grains within the IRD fraction in majority of the cores advocate a dual origin for the sediment input: quartz from the Antarctic craton and volcanic material from the islands in the vicinity of the study area. Hydrographic advection from south via the bottom and deep waters appears to be the most important mechanism supplying fine detrital clays to the study area throughout the late Quaternary. The Holocene and interglacial periods are characterized by low MS, low sand fraction, reduced ice-rafted detritus (IRD) input as well as an increased input of illite clays possibly from south. The glacial intervals reveal large increase in MS, sand fraction and greatly increased IRD input, related to the northward migration of Polar Front. Significant reduction in clay fraction, illite content, as well as increase in IRDs and MS suggest that the erosive and transporting capabilities of the deep and bottom waters at the core sites during glacial periods could have reduced compared to the modern times.

\section{Acknowledgements}

The Pilot Expedition to Southern Ocean (PESO) was funded by the Department of Ocean Development (DOD), Government of India. We are extremely grateful to the captain and crew of the 200th expedition of ORV Sagar Kanya for their excellent support in hostile conditions. Sincere thanks to V Purnachandra Rao and Girish Prabhu from NIO, Goa for XRD analyses. We are thankful to K Naik, N Parsekar and B L Redkar for laboratory assistance. Thanks are due to N Anilkumar for discussions on the physical oceanography of the region and $\mathrm{V}$ Yatheesh for help with bathymetry. Sincere thanks are also due to two anonymous reviewers for improving the quality of the manuscript.

\section{References}

Anilkumar N, Dash M K, Luis A J, Ramesh Babu V, Somayajulu Y K, Sudhakar M and Pandey P C 2005 Oceanic fronts along $45^{\circ} \mathrm{E}$ across Antarctic Circumpolar Current during austral summer 2004; Curr. Sci. 88 1669-1673.

Bareille G, Grousset F E, Labracherie M, Labeyrie L D and Petit J R 1994 Origin of detrital fluxes in the southeast Indian Ocean during the last climate cycles; Paleoceanography 9 799-819.

CLIMAP Project 1976 The surface of the Ice-Age Earth; Science 191 1131-1137.

Crosta X and Shemesh A 2002 Reconciling the down core anticorrelation of diatom carbon and nitrogen isotopic ratios from the Southern Ocean; Paleoceanography $\mathbf{1 7}$ 10.1029/2000PA000565.

Crosta X, Pichon J J and Burckle L H 1998 Application of modern analogue technique to marine Antarctic diatoms: Rectonstruction of the maximum sea ice extent at the Last Glacial Maximum; Paleoceanography 13 284-297.

Deikmann B, Fütterer D K, Grobe H, Hillenbrand C D, Kuhn G, Michels K, Petschick R and Pirrung M 2004 Terrigenous sediment supply in the polar to temperate South Atlantic: Land-Ocean links of environmental changes during the late Quaternary; In: The South Atlantic in the late Quaternary: Reconstruction of material budgets and current systems (eds) G Wefer, S Mulitza and V Ratmeyer (Springer-Verlag: Berlin), pp. 375-399.

Dezileau L, Bareille G, Reyss J L and Lemoine F 2000 Evidence for strong sediment redistribution by bottom currents along the southeast Indian ridge; Deep Sea Res. I 47 1899-1936.

Ehrmann W U and Grobe H 1991 Cyclic sedimentation at sites 745 and 746; Proc. ODP In. Results 119 225-235. 
Ellwood B B, Crick R E, Hassani A E, Benoist S L and Young R H 2000 Magnetic susceptibility event and cyclostratigraphy method applied to marine rocks: Detrital versus carbonate productivity; Geology $\mathbf{2 8}$ $1135-1138$.

Frederichs T, Bleil U, Däumler K, von Dobeneck T and Schmidt A M 1999 The magnetic view on the marine paleoenvironment: Parameters, techniques and potentials of rock magnetic studies as a key to palaeoclimatic and paleoceanographic changes; In: Use of proxies in paleoceanography: Examples from the South Atlantic (eds) G Wefer and G Fischer (Springer-Verlag: Berlin), pp. 575-599.

Klinck J M and Smith D A 1993 Effect of wind changes during the Last Glacial Maximum on the circulation in the Southern Ocean; Paleoceanography 8 427-433.

Knox F and McElroy M B 1985 Changes in the atmospheric $\mathrm{CO}_{2}$ : Factors regulating the glacial to interglacial transition; In: The Carbon cycle and atmospheric $\mathrm{CO}_{2}$ : Natural variations from Archean to Present (eds) E Sundquist and W Broecker, Geophys. Monogr. Ser. 32 (AGU: Washington DC), 154-162.

Kolla V, Henderson L, Sullivan L and Biscaye P E 1978 Recent sedimentation in the southeast Indian Ocean with special reference to the effects of Antarctic bottom water circulation; Mar. Geol. 27 1-17.

Kolla V, Sullivan L, Streeter S S and Langseth Jr. M G 1976 Spreading of Antarctic Bottom water and its effects on the floor of the Indian Ocean inferred from bottom water potential temperature, turbidity and sea-floor photography; Mar. Geol. 21 171-189.

Labeyrie L D, Labracherie M, Gorfti N, Pichon J J, Vautravers M, Arnold M, Duplessy J C, Paterne M, Michel E, Duprat J, Caralp M and Turon J L 1996 Hydrographic changes of the Southern Ocean (southeast Indian sector) over the last $230 \mathrm{kyr}$; Paleoceanography 11 57-76.

Labeyrie L D, Pichon J J, Labracherie M, Ippolito P, Duprat J and Duplessy J C 1986 Melting history of Antarctic during the past 60,000 years; Nature 322 701-706.

Mackensen A 2004 Changing Southern Ocean paleocirculation and effects on global climate; Antarctic Science $\mathbf{1 6}$ 369-386.
Martin J 1990 Glacial-interglacial $\mathrm{CO}_{2}$ change: The iron hypothesis; Paleoceanography 5 1-13.

McCave I 1986 Local and global aspects of the bottom nepheloid layers in the world ocean; Netherlands J. Sea Res. 20 167-181.

Park Y H, Gamberoni L and Charriaud E 1993 Frontal structure, water masses and circulation in the Crozet Basin; J. Geophys. Res. 98 12,361-12,385.

Petit J R, Mounier L, Jouzel J, Korotkevich Y S, Kotlyakov V I and Lorius C 1990 Palaeoclimatological and chronological implications of the Vostok core dust record; Nature $34356-58$.

Pirrung M, Hillenbrand C D, Deikmann B, Fütterer D K, Grobe H and Kuhn G 2002 Magnetic susceptibility and ice-rafted debris in surface sediments of the Atlantic sector of the Southern Ocean; Geo-Mar. Lett. 22 170-180.

Pudsey C J and Howe J A 1998 Quaternary history of the Atlantic Circumpolar Current: Evidence from the Scotia Sea; Mar. Geol. 148 83-112.

Schmieder F 2004 Magnetic signals in Plio-Pleistocene sediments of the South Atlantic: Chronostratigraphic usability and paleoceanographic implications; In: The South Atlantic in the late Quaternary: Reconstruction of material budgets and current systems (eds) G Wefer, S Mulitza and V Ratmeyer (Springer-Verlag: Berlin), pp. 261-277.

Thamban M, Rao V P and Schneider R R 2002 Reconstruction of late Quaternary monsoon oscillations based on clay mineral proxies using sediment cores from the western margin of India; Mar. Geol. 186 533-545.

Toggweiler R and Sarmiento J 1985 Glacial to interglacial changes in the atmospheric carbon dioxide: The critical role of the surface water in high latitudes; In: The Carbon cycle and atmospheric $\mathrm{CO}_{2}$ : Natural variations from Archean to Present (eds) E Sundquist and W Broecker, Geophys. Monogr. Ser. 32 (AGU: Washington DC), 99-110.

von Dobeneck T and Schmieder F 1999 Using rock magnetic proxy records for orbital tuning and extended time series analyses into the super- and sub-Milankovitch bands; In: Use of proxies in paleoceanography: Examples from the South Atlantic (eds) G Wefer and G Fischer (Springer-Verlag: Berlin), pp. 601-633. 